\title{
HUBUNGAN STRUKTURAL KUALITAS LAYANAN, KUALITAS PRODUK, KEPUASAN PELANGGAN, DAN NIAT ULANG BERKUNJUNG KE PANTAI LONG MALANG DI SAMPANG
}

\author{
Pribanus Wantara ${ }^{1}$, Muhammad Tambrin ${ }^{2}$ \\ ${ }^{1}$ Universitas Trunojoyo Madura, pribanus.wantara@trunojoyo.ac.id \\ ${ }^{2}$ Universitas Trunojoyo Madura, tambrin@trunojoyo.ac.id
}

\begin{tabular}{ll|lll}
\hline Article history & \multicolumn{3}{l}{} \\
\hline Dikirim tanggal & $: 09 / 06 / 2021$ & Diterima tanggal & $:$ & $19 / 08 / 2021$ \\
Revisi pertama tanggal & $: 18 / 08 / 2021$ & Tersedia online tanggal & $:$ & $08 / 09 / 2021$ \\
\hline
\end{tabular}

\begin{abstract}
ABSTRAK
Tujuan penelitian ini adalah untuk menguji hubungan struktural antara kualitas pelayanan, kualitas produk, kepuasan pelanggan, dan niat ulang berkunjung. Penelitian ini dilakukan pada kondisi pandemi Covid 19 dan dilakukan pada sebuah destinasi wisata pantai yang berada di Kabupaten Sampang, Madura. Responden dalam penelitian ini sebanyak 187 wisatawan lokal yang bersedia menyelesaikan penelitian ini. Analisa Structural Equation Modelling (SEM) digunakan untuk menganalisa hubungan. Hasil penelitian menunjukkan bahwa kualitas layanan memberikan pengaruh signifikan terhadap kepuasan wisatawan, namun kualitas produk tidak memberi pengaruh signifikan terhadap kepuasan wisatawan, temuan selanjutnya adalah kepuasan memberikan pengaruh signifikan terhadap niat ulang berkunjung pada tempat atau destinasi wisata pantai Long Malang di Kabupaten Sampang, Madura.
\end{abstract}

Kata Kunci: kualitas layanan, kualitas produk, kepuasan dan niat ulang berkunjung.

\begin{abstract}
The purpose of this study was to examine the structural relationship between service quality, product quality, customer satisfaction, and re-visit intention. This research was conducted in the conditions of the Covid 19 pandemic and was carried out at a coastal tourist destination in Sampang Regency, Madura. Respondents in this study were 187 local tourists who were willing to complete this research. Analysis of Structural Equation Modeling (SEM) is used to analyze relationships. The results showed that service quality had a significant influence to tourist satisfaction, but the product quality did not have a significant effect on tourist satisfaction, and satisfaction have a significant effect on re-visit intention to tourist destinations in Long Malang beach of the Sampang Regency, Madura.
\end{abstract}

Keywords: service quality, product quality, satisfaction and re-visit intention.

\section{PENDAHULUAN}

Memasuki tahun ke-dua masa pandemi Covid 19 berlangsung, berbagai aktivitas perekonomian di Indonesia bahkan dunia mengalami dampaknya. Demikian pula dialami oleh masyarakat Madura, akibat pandemi sektor perekonomian dan khususnya pariwisata juga mengalami dampaknya. Namun dengan menurunnya jumlah kasus pandemi di Pulau Madura, geliat perekonomian khususnya dalam sektor pariwisata di Pulau Madura sudah mulai meningkat. Tempat destinasi wisata khususnya wisata pantai sudah mulai dibuka dan mendapat kunjungan para wisatawan lokal walaupun masih terbatas. 
Industri pariwisata merupakan salah satu dari beberapa cara untuk meningkatkan kemajuan ekonomi masyarakat. Maka tidak heran jika industri pariwisata dikategorikan sebagai sektor ekonomi yang penting. Pariwisata telah menjadi kegiatan sosial ekonomi dan industri dalam skala besar yang menghasilkan pertumbuhan ekonomi, khususnya pada kondisi pandemi Covid 19. Mengingat pentingnya industri pariwisata bagi kemajuan ekonomi, berbagai upaya telah dilakukan untuk menarik wisatawan baik domestik maupun internasional, antara lain dengan meningkatkan dan menambah sarana dan prasarana untuk meningkatkan kepuasan dan minat berkunjung kembali.

Dalam kondisi New Normal Covid 19, upaya memahami pentingnya lingkungan pelayanan dalam memuaskan dan mempertahankan konsumen adalah sangat penting bagi dunia bisnis. Lingkungan pelayanan juga merupakan faktor penting dalam menggapai profitabilitas khususnya pada industri pariwisata (Macintosh \& Doherty, 2007). Dalam beberapa tahun terakhir, para peneliti telah melakukan upaya bersama untuk memahami kualitas pelayanan yang terkait dengan industri pariwisata. Perhatian khusus telah diberikan pada industri pariwisata yang menawarkan pelayanan kepada konsumen umum dengan berbagai latar belakang sosiodemografi (Tsuji, Bennett, \& Zhang, 2007). Berbagai kalangan wisatawan telah ditemukan memiliki efek lengsung yang signifikan pada jumlah kunjungan pada sebuah pelayanan rekreasi (Lamb, Asturias, Roberts, \& Brodie, 1992). Oleh karena itu, penting dan perlu untuk memahami penilaian konsumen yang sangat butuh terhadap destinasi wisata khususnya berkaitan dengan kualitas pelayanan, kualitas produk, kepuasan pelanggan, dan niat perilaku, dan hubungan diantara variabel-variabel ini, karena mereka adalah faktor inti mengenai keefektifan program wisata, sehingga dapat dikatakan bahwa tingkat kepuasan pengguna selain dapat menentukan kemungkinan terjadinya niat membeli ulang (atau niat berkunjung kembali), tingkat kepuasan juga ditentukan oleh variabel kualitas produk (Jahanshahi et al., 2011; Amanah, 2010), dan kualitas layanan (Sharma, 2012; Hassan et al, 2013). Beberapa peneliti lainnya juga telah meneliti hubungan langsung dan tidak langsung antara kualitas pelayanan, kualitas produk, kepuasan pelanggan, dan niat ulang berkunjung. Woodruff (1997) menegaskan bahwa kualitas pelayanan merupakan variabel anteseden utama terhadap kepuasan pelanggan, dan niat ulang berkunjung. Chang dan Wildt (1994) juga melaporkan bahwa kualitas pelayanan yang dipersepsikan memiliki pengaruh yang kuat dan positif terhadap kepuasan, yang pada gilirannya, mempengaruhi niat ulang berkunjung. Oliver (1999) menambahkan bahwa sikap niat pelanggan untuk menggunakan (mengulang) kembali ini berkaitan erat dengan kepuasan terhadap produk baik terhadap barang maupun jasa serta berlangganan dan memberikan informasi positif tentang produk tersebut kepada konsumen lainnya.

Meningkatkan jumlah kunjungan kembali sangat penting dalam industri pariwisata (Ayuningtiyas, Nimran, \& Hamid, 2014) dan niat kunjungan kembali dianggap sebagai salah satu masalah terpenting dalam pemasaran kontemporer $(\mathrm{Wu}, \mathrm{Ai}$, Yang, \& Li, 2015). Yang menjadi tantangan adalah bagaimana mendorong para pengunjung untuk mengunjungi kembali pada destinasi tersebut (Ayuningtiyas et al., 2014). Mitos dalam pemasaran pada umumnya adalah lima sampai enam kali lebih efektif untuk mempertahankan pelanggan yang loyal daripada mendapatkan pelanggan baru. Meskipun demikian, ada beberapa penelitian tentang hubungan antara kepuasan dan niat perilaku selama proses pemilihan tujuan pasca pembelian (Guntoro \& Hui, 2013). Untuk menjawab tantangan ini, maka tujuan dalam studi ini adalah untuk meneliti hubungan antara kualitas pelayanan, kualitas produk, kepuasan pelanggan, dan niat ulang berkunjung pada sebuah destinasi wisata pantai Long Malang yang berada di Kabupaten Sampang. 


\section{KAJIAN PUSTAKA}

\section{Kualitas Pelayanan}

Pada New Normal Covid 19 saat ini, kualitas pelayanan merupakan elemen penting bagi pengelola destinasi wisata dalam rangka mempertahankan dan meningkatkan basis pelanggan mereka, mengembangkan keunggulan kompetitif, dan menghasilkan pendapatan yang berkelanjutan dari pelanggan mereka. Gagasan ini juga berlaku untuk program wisata yang ditargetkan pada kelompok konsumen wisatawan lokal Madura. Tjiptono \& Chandra $(2011,198)$ mengidentifikasi ada lima dimensi kualitas pelayanan, yaitu:

a. Reliabilitas atau Keandalan (reliability). Merupakan kemampuan perusahaan menyediakan layanan yang terpercaya dan akurat sejak awal tanpa membuat kesalahan apapun dan menyampaikan pelayanannya sesuai dengan waktu yang disepakati. Hal ini berarti tingkat kehandalan di mata pelanggan, meliputi kemampuan memberikan layanan yang dijanjikan dengan segera, akurat, dan memuaskan.

b. Daya Tanggap (responsiveness). Berkenaan dengan kesediaan dan kemampuan para karyawan dalam membantu para pelanggan atau merespon permintaan mereka, serta menginformasikan kapan pelayanan akan disampaikan serta disampaikan secara cepat. Apapun posisi seseorang dalam perusahaan hendaknya selalu memperhatikan pelanggan yang menghubungi perusahaan;

c. Jaminan (assurance). Perilaku para karyawan yang mampu menumbuhkan kepercayaan kepada pelanggan tentang perusahaan seperti karyawan memiliki pengetahuan, kesopansantuanan, dan kemampuan para pegawai perusahaan sehingga dapat menumbuhkan rasa percaya pelanggan kepada perusahaan.

d. Empati (empathy). Berarti bahwa perusahaan memahami masalah para pelanggannya dan bertindak demi kepentingan pelanggan, serta memberikan perhatian personal kepada para pelanggan dan memiliki jam operasi yang nyaman. Setiap anggota perusahaan hendaknya dapat mengelola waktu agar mudah dihubungi, baik melalui telepon ataupun bertemu langsung;

e. Bukti langsung (tangible). Berkenaan dengan daya tarik fasilitas fisik, perlengkapan, dan material yang digunakan perusahaan, serta penampilan karyawan. Dalam hal ini sarana dan prasarana yang berkaitan dengan layanan pelanggan harus diperhatikan oleh manajemen perusahaan.

\section{Kualitas produk}

Kualitas produk adalah kemampuan suatu produk untuk menjalankan fungsifungsi tertentu, yang dapat terdiri dari: daya tahan, keandalan, akurasi yang dihasilkan, kemudahan penggunaan dan perbaikan, dan atribut berharga lainnya produk secara holistik (Amanah, 2010). Agar pemasaran suatu produk dapat berjalan, konsumen perlu merasakan kompatibilitas dengan kualitas produk dan mereka cenderung membeli produk yang sesuai dengan apa yang mereka inginkan atau butuhkan. Dengan kata lain, pembuatan atau desain produk harus berorientasi pada apa yang diinginkan pasar atau preferensi pelanggan, seperti produk yang berkualitas tinggi. Indikator produk yang mendukung penelitian ini seperti dikutip dari tulisan yang disampaikan oleh Diapinsa (2017) meliputi:

1) Produk-produk yang ditawarkan menarik

2) Produk-produk yang ditawarkan memenuhi keinginan dan kebutuhan.

3) Produk-produk yang ditawarkan bermutu 


\section{Kepuasan}

Menurut Kotler \& Keller (2016), kepuasan pelanggan adalah derajat emosi seseorang setelah membandingkan kinerja atau hasil yang dirasakannya dengan harapannya. Chen dan Tsai (2007) mendefinisikan "kepuasan wisatawan sebagai persepsi atau perasaan positif yang dikembangkan atau diperoleh wisatawan dengan terlibat dalam kegiatan rekreasi dan dinyatakan sebagai tingkat kesenangan yang diperoleh dari pengalaman tersebut". Dalam industri pariwisata, kepuasan wisatawan sangat penting karena memiliki efek langsung pada pilihan destinasi. Dengan mengutip pada riset yang dilakukan oleh Wahyu, Sukimin, dan Nina, (2020) dan kemudian dimodifikasi sesuai dengan kondisi penelitian kali ini, dimana indikator yang digunakan meliputi:

a. Re-purchase: Membeli kembali, dimana pelanggan tersebut akan kembali kepada perusahaan untuk membeli.

b. Menciptakan Word-of-Mouth: Dalam hal ini, pelanggan akan mengatakan hal-hal yang baik tentang perusahaan kepada orang lain

c. Menciptakan Citra Merek: Pelanggan akan kurang memperhatikan merek dan atau iklan dari produk pesaing/lain.

d. Menciptakan keputusan Pembelian pada Perusahaan yang sama: Membeli jasa atau produk lainnya pada perusahaan yang sama.

\section{Minat Berkunjung Ulang}

Minat menurut Schiffman dan Kanuk (2007:201) merupakan aktivitas psikis yang timbul karena adanya perasaan dan pikiran terhadap suatu barang atau jasa yang diinginkan, sehingga menimbulkan rasa ingin memiliki, merasakan ataupun mengunjungi. Selanjutnya Oliver (1997) mendefinisikan minat perilaku (di antaranya, pembelian kembali dan niat dari mulut ke mulut) sebagai "situasi di mana segala sesuatu terhubung dalam suatu perilaku. Sedangkan Baker dan Crompton, (2000), dengan melihat dari sudut pandang liburan dan rekreasi, maka niat perilaku ulang adalah niat dari pengunjung untuk mengunjungi kembali situs dalam setahun dan niatnya untuk sering datang ke tempat tujuan. Dikutip dari Zhafira, dan Putu Yudi, 2018, maka indikator dari minat berkunjung ulang dalam penelitian ini adalah:

a. Mengunjungi kembali, seperti: datang berkunjung kembali ke objek wisata Pantai Long Malang di waktu yang akan datang.

b. Merekomendasikan, seperti: menceritakan objek wisata Pantai Pantai Long Malang kepada orang atau pihak lain tentang objek wisata Pantai Long Malang.

c. Mengajak untuk berkunjung, seperti: mengajak orang lain untuk berkunjung ke objek wisata Pantai Long Malang

\section{Hubungan Kualitas Pelayanan dan Kepuasan}

Yiannakis (1989) menunjukkan bahwa perhatian kritis dalam pemasaran wisata adalah memantau kepuasan / ketidakpuasan konsumen, kebutuhan, keinginan, harapan, dan perubahan preferensi sehingga dapat secara efisien mengidentifikasi variabel kontingensi yang mungkin berhubungan dengan pengembangan rencana pemasaran strategis.

Dalam upaya memahami ketidakpuasan konsumen terhadap pelayanan telah banyak menghasilkan penelitian berkaitan dengan kualitas pelayanan dan kepuasan konsumen (seperti disampaikan oleh Wantara, 2015), demikian juga yang disampaikan oleh Woodruff (1997) bahwa kualitas pelayanan merupakan variabel anteseden utama terhadap kepuasan pelanggan, serta menurut Chang dan Wildt (1994) yang melaporkan 
bahwa kualitas pelayanan yang dipersepsikan memiliki pengaruh kuat dan positif terhadap kepuasan.

\section{Hubungan kualitas produk dan kepuasan}

Konsumen akan merasa puas apabila produk yang mereka gunakan berkualitas tinggi (Bei \& Chiao, 2001). Sementara itu, Jahanshahi dkk. (2011), Amanah (2010) dan Brucks et al. (2000) membuktikan bahwa kualitas suatu produk yang dirasakan konsumen merupakan faktor yang mempengaruhi kepuasan konsumen. Demikian pula yang disampaikan oleh Etemat-Sajadi \& Rizzuto (2013) yang berpendapat bahwa kualitas produk berpengaruh positif terhadap kepuasan pelanggan. Selanjutnya Kotler and Keller (2012:316) mendefinisikan kualitas produk sebagai kemampuan suatu barang untuk memberikan hasil/kinerja yang sesuai atau melebihi dari apa yang diinginkan pelanggan. Segala sesuatu yang dapat ditawarkan ke pasar untuk mendapatkan perhatian, dibeli, digunakan, atau dikonsumsi yang dapat memuaskan keinginan atau kebutuhan.

\section{Hubungan Kepuasan dan Niat Ulang Berkunjung}

Meskipun niat berperilaku dapat berubah karena kejadian atau interval waktu yang tidak terduga, namun niat dianggap sebagai anteseden langsung dari perilaku aktual (Kwon, Trail, \& James, 2007). Kualitas pelayanan yang tinggi dan ditunjang dengan pengalaman yang positif seringkali mengarah pada kepuasan dan niat perilaku yang baik terhadap penyedia pelayanan (Hoch \& Deighton, 1989). Demikian juga tentang kualitas produk, apabila tidak memenuhi harapan, maka pelanggan merasa tidak puas, dan ini dapat mempengaruhi terhadap perilaku mereka selanjutnya (Sambandam \& Lord, 1995). Pelanggan yang tidak puas cenderung memiliki niat ulang berkunjung lebih rendah dan cenderung berperilaku untuk menyampaikan keluhan atau komplain daripada pelanggan yang merasa puas (Zhang et al., 2011). Ngoc \& Trinh, (2015) dalam penelitiannya, menyatakan bahwa kepuasan wisatawan berpengaruh positif dan signifikan terhadap niat mengunjungi kembali suatu destinasi. Hasil penelitian ini didukung oleh Meng \& Han, 2018, dikatakan dalam penelitiannya, bahwa kepuasan wisatawan memiliki hubungan positif dan signifikan terhadap niat berkunjung kembali. Hal ini dapat terjadi karena ketika wisatawan merasa puas dengan suatu destinasi wisata, wisatawan akan mengunjungi kembali tempat wisata tersebut. Chen \& Tsai, (2007); sepakat bahwa kepuasan menyebabkan wisatawan kembali ke tujuan yang sama dan berbagi informasi positif tentang destinasi yang telah dikunjungi. Selanjutnya Dayour dan Adango (2015) mengabstraksikan bahwa, wisatawan yang puas akan mengunjungi kembali destinasi terkait atau membagikan informasi positif tentang destinasi tersebut kepada orang lain.

\section{Hipotesa}

Dari beberapa uraian definisi yang telah disampaikan, maka diajukan hipotesis berikut dalam konteks sebuah destinasi wisata pantai Long Malang:

Hipotesis 1 : Kualiatas pelayanan memberikan hubungan signifikan terhadap kepuasan.

Hipotesis 2 : Kualiatas produk memberikan hubungan signifikan terhadap kepuasan.

Hipotesis 3 : Kepuasan memberikan hubungan signifikan terhadap niat ulang berkunjung. 


\section{METODOLOGI PENELITIAN}

Penelitian ini menggunakan pendekatan kuantitatif dan termasuk kedalam penelitian yang bersifat asosiatif, karena penilitian ini bertujuan untuk menguji hubungan antara variabel variabel kualitas pelayanan dan kualitas produk terhadap niat pembelian ulang yang dimediasi oleh kepuasan pengunjung atau wisatawan yang mengunjungi destinasi wisata Long Malang yang berada di Kabupaten Sampang. Variabel bebas atau eksogen dalam penelitian ini adalah kualitas pelayanan yang disimbolkan dengan X1 dan kualitas produk yang disimbolkan dengan X2. Variabel terikat atau endogen dalam penelitian ini adalah kepuasan pelanggan yang disimbolkan dengan Y1 dan niat berkunjung kembali yang disimbolkan dengan Y2.

Tabel 1.

Indikator Penelitian

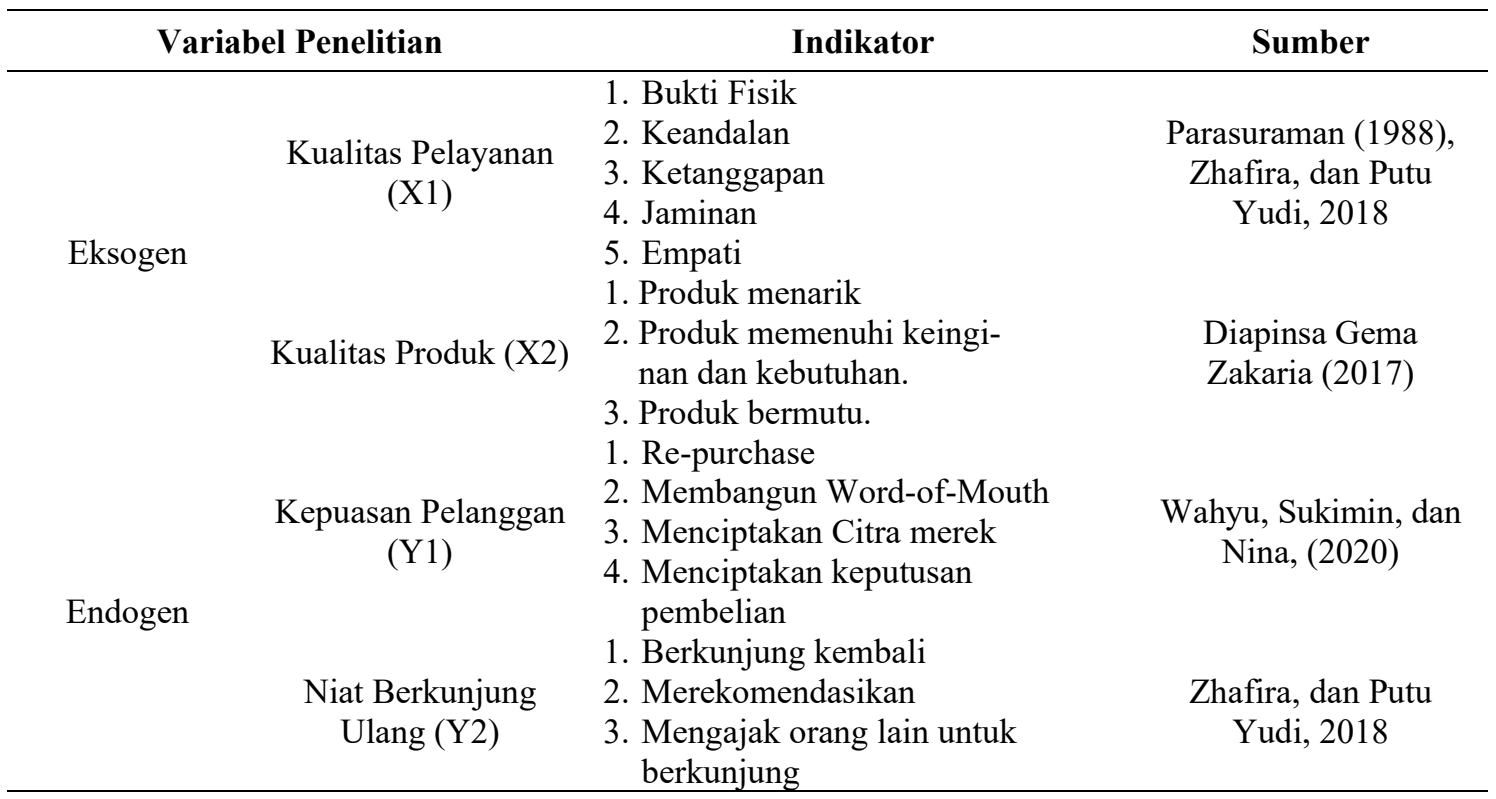

Sumber: Kajian terhadap beberapa Penelitian sebelumnya, 2021

Populasi dalam penelitian ini adalah para pengunjung atau wisatawan yang mengunjungi destinasi wisata Long Malang yang berada di Kabupaten Sampang serta minimal satu kali berkunjung. Penelitian ini menggunakan metode sampel non probability sampling dengan teknik purposive sampling, dengan jumlah responden sebanyak 187 orang. Metode pengumpulan data dalam penelitian ini adalah metode survei dengan teknik wawancara menggunakan kuisioner.

\section{Metode Analisis Data}

Untuk menganalisa data, pencapaian tujuan penelitian serta pengujian hipotesis yang diajukan, maka data yang diperoleh selanjutnya akan diolah sesuai dengan kebutuhan analisis. Teknik yang digunakan adalah teknik analisis statistik deskriptif dan statistik inferensial.

Analisa statistik deskriptif ditujukan untuk mengidentifikasi karakteristik masing-masing variabel dalam bentuk frekuensi dan persentase, sedangkan statistik inferensial merupakan teknik statistik yang digunakan untuk menganalisis data sampel dan hasilnya diberlakukan untuk populasi. Statistik ini akan cocok digunakan bila sampel diambil dari populasi yang jelas, dan teknik pengambilan sampel dari populasi 
itu dilakukan secara random (Sugiyono, 2001). Selanjutnya analisis yang digunakan untuk menjawab hipotesis dalam penelitian ini digunakan Model Persamaan Struktur (Structur Equation Model atau SEM) dengan menggunakan paket program SPSS 16 dan Amos 16.0. Analisis ini diharapkan dapat membantu kita untuk memahami model mana yang paling sesuai dengan data sambil menyajikan penilaian yang kredibel pada anteseden niat ulang berkunjung wisatawan pada destinasi wisata Pantai Long Malang. Pendugaan parameter atau Goodness of Fit Indices yang digunakan ditampilkan pada Tabel 2.

Tabel 2.

Goodness of Fit Indices

\begin{tabular}{clc}
\hline No. & Good of Fit Index & Cut-Off \\
\hline 1 & Chi-Square & Diharapkan Kecil \\
2 & Probability & $\geq 0,05$ \\
3 & CMIN/DF & $\leq 2,00$ \\
4 & GFI & $\geq 0,90$ \\
5 & AGFI & $\geq 0,90$ \\
6 & TLI & $\geq 0,95$ \\
7 & CFI & $\geq 0,95$ \\
8 & RMSEA & $\leq 0,08$ \\
\hline
\end{tabular}

Sumber: Data diolah.

\section{HASIL DAN PEMBAHASAN}

\section{Karakteristik Responden}

Daftar kuesioner dibagikan kepada para wisatawan Pantai Long Malang. Selama kurun waktu satu bulan. Direncanakan sebanyak 200 kuesioner yang akan disebarkan kepada wisatawan, namun terdapat 187 kuesioner yang berhasil dikumpulkan secara sempurna oleh responden yang bersedia. Selanjutnya dari responden tersebut, 41 persen adalah laki-laki dan 59 persen perempuan. Gambaran tentang responden yang bersedia mendukung penelitian ini ditampilkan pada Tabel 3:

Tabel 3.

Demografi Responden

\begin{tabular}{llcc}
\hline $\begin{array}{l}\text { Variabel } \\
\text { Demografis }\end{array}$ & Kategori & $\begin{array}{c}\text { Jumlah } \\
\text { sampel }\end{array}$ & Persentase \\
\hline Jenis Kelamin & Male & 107 & 59 \\
Usia & Female & 80 & 41 \\
& $\leq 18$ & 4 & 2 \\
& $19-23$ & 24 & 12 \\
& $24-28$ & 61 & 31 \\
& $29-33$ & 59 & 35 \\
Tingkat Pendidikan & 18 & 9 \\
& $34-38$ & 16 & 8 \\
& $39-43$ & 6 & 3 \\
& Pascasarjana & 12 & 6 \\
& Diploma & 36 & 23 \\
& SMA atau setara & 44 & 22 \\
& SMP atau setara & 95 & 49 \\
\hline
\end{tabular}




\section{Reliability Analysis}

Analisa reliabilitas digunakan untuk mengukur sejauh mana kuesioner, pengujian, observasi atau prosedur pengukuran menghasilkan hasil yang sama pada percobaan yang berulang (Babbie, 2004). Menurut Du Plessis (2010: 12), ketika menghitung Cronbach's alpha dan hasilnya di atas 0,60 maka mencerminkan tingkat akseptabilitas lebih baik. Statistik reliabilitas terhadap kuesioner disajikan pada Tabel 4.

Tabel 4.

Reliability statistics

\begin{tabular}{lcc}
\hline \multicolumn{1}{c}{ Konstruk } & Cronbach's alpha & Jumlah item \\
\hline Kualitas Pelayanan & 0.767 & 5 \\
Kualitas Produk & 0.728 & 3 \\
Kepuasan Pelanggan & 0.733 & 4 \\
Niat ulang berkunjung & 0.726 & 3 \\
\hline
\end{tabular}

Sumber: data diolah, 2021

Terbukti pada Tabel 4 bahwa koefisien atau alpha reliabilitas untuk berbagai konstruk dihitung menggunakan prosedur reliabilitas pada SPSS versi 16. Hasil uji reliabilitas dalam penelitian ini menunjukkan bahwa semua konstruk yang dinilai reliabel karena semuanya memiliki alpha cronbach dan reliabilitas konstruk. di atas 0,7 standar yang ditetapkan oleh Nunnally (1978), yaitu 0,70. Rentang alfa Cronbach menunjukkan reliabilitas variabel penelitian berkisar antara $\alpha=0,726$ hingga $\alpha=0,767$; skor rata-rata telah dihitung dengan membobotkan skor rata-rata dari semua item yang relevan untuk setiap konstruk.

\section{Pengujian Hipotesa}

Jalur dalam penelitian ini meliputi tiga jalur langsung (direct effect), dimana hasil penghitungan atau koefisien jalur masing-masing hubungan dapat dilihat pada Tabel 5 berikut:

Tabel 5.

Hasil Hipotesis Penelitian Direct effect

\begin{tabular}{lccc}
\hline \multicolumn{1}{c}{ Pengaruh antar Variabel } & $\begin{array}{c}\text { Koef. Jalur } \\
\text { Standardize }\end{array}$ & $\boldsymbol{p}$-value & Keterangan \\
\hline 1. Kepuasan $\leftarrow$ Kualitas Jasa & 0.886 & 0,000 & Signifikan \\
\hline 2. Kepuasan $\leftarrow$ Kualitas Produk & 0.213 & 0,259 & Tidak Signifikan \\
3. Niat ulang $\leftarrow$ Kepuasan & 0.816 & 0.007 & Signifikan \\
\hline
\end{tabular}

Sumber: Data primer, diolah 2021

Berdasarkan tabel 5 di atas, dapat dikatakan bahwa hubungan pengaruh secara parsial diperoleh hasil bahwa dari ketiga hubungan langsung, ternyata terdapat dua hubungan yang berpengaruh signifikan dan satu hubungan yang tidak berpengaruh signifikan. Selanjutnya hasil penghitungan terhadap Goodness of Fit Indices secara total digambarkan pada Tabel 6 berikut: 
Tabel 6.

Goodness of Fit Indices

\begin{tabular}{clccc}
\hline No. & Good of Fit Index & Cut-Off & Hasil & Keterangan \\
\hline 1 & Chi-Square & Diharapkan Kecil & 131,144 & Kecil \\
2 & Probability & $\geq 0,05$ & 0,130 & Bagus \\
3 & CMIN/DF & $\leq 2,00$ & 1,150 & Bagus \\
4 & GFI & $\geq 0,90$ & 0,930 & Bagus \\
5 & AGFI & $\geq 0,90$ & 0,906 & Bagus \\
6 & TLI & $\geq 0,95$ & 0,971 & Bagus \\
7 & CFI & $\geq 0,95$ & 0,976 & Bagus \\
8 & RMSEA & $\leq 0,08$ & 0,028 & Bagus \\
\hline
\end{tabular}

Sumber: Data diolah, 2021

Pada Tabel 6 di atas, yang menggambarkan hubungan secara keseluruhan (simultan) diperoleh hasil bahwa model secara total memiliki hasil nilai yang bagus sehingga model secara keseluruhan yang digambarkan pada Gambar 1, dapat dikatakan layak untuk digunakan dalam menjelaskan penelitian ini. Model struktural yang menghubungkan variabel kualitas layanan, kualitas produk, kepuasan pelanggan dan niat ulang berkunjung dalam struktur model ditampilkan pada Gambar 1.

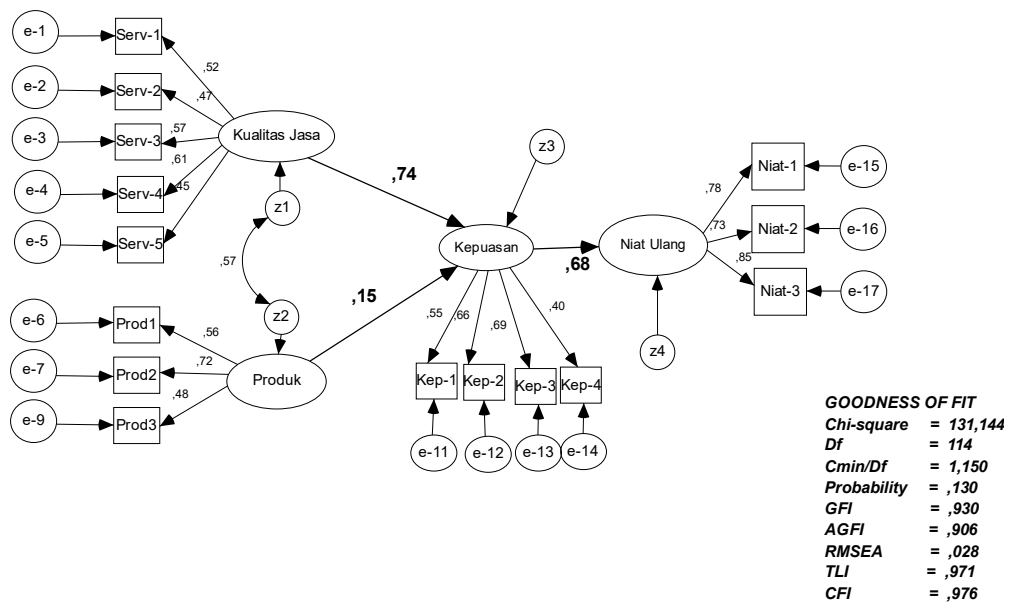

Gambar 1. Model Pengukuran

Berdasarkan Tabel 5, Tabel 6, serta Gambar 1, maka dihasilkan pengujian hipotesis sebagai berikut:

1. Koefisien jalur kualitas jasa (layanan) terhadap kepuasan ditunjukkan dengan loading factor positif sebesar 0,735 dengan nilai probabilitas ( $p$-value $=0,000$ ) lebih kecil daripada $0,01 \quad(<\alpha=0,01)$. Dengan demikian hipotesis yang menyatakan bahwa kualitas layanan berpengaruh signifikan terhadap kepuasan, diterima. Hasil ini menunjukkan bahwa dengan meningkatkan kualitas layanan maka akan meningkatkan kepuasan para wisatawan terhadap destinasi wisata pantai dengan peningkatan yang signifikan.

2. Koefisien jalur kualitas produk terhadap kepuasan ditunjukkan dengan loading factor positif sebesar sebesar 0,155 dengan nilai probabilitas ( $\mathrm{p}$-value) sebesar 0,259 lebih besar daripada $0,05(>\alpha=0,05)$. Dengan demikian hipotesis yang menyatakan kualitas produk berpengaruh signifikan terhadap kepuasan, tidak 
diterima. Hasil ini menunjukkan bahwa peningkatan kualitas produk pada penelitian ini tidak menimbulkan pengaruh terhadap kepuasan para wisatawan.

3. Koefisien jalur kepuasan terhadap niat ulang berkunjung menunjukkan hubungan positif dengan nilai loading factor sebesar 0,681 dengan nilai probabilitas ( $\mathrm{p}$ value) sebesar 0,000 lebih kecil daripada $0,01(<\alpha=0,01)$. Dengan demikian hipotesis yang menyatakan kepuasan berpengaruh signifikan terhadap niat ulang berkunjung ke destinasi wisata pantai Long Malang, diterima. Hasil ini menunjukkan bahwa peningkatan kepuasan secara signifikan meningkatkan niat ulang untuk berkunjung ke tempat lokasi wisata Pantai Long Malang.

\section{HASIL DAN PEMBAHASAN}

Hubungan yang dihipotesiskan di antara konstruksi yang diusulkan untuk diuji, dan ditemukan memiliki tingkat kecocokan yang memadai $(\mathrm{CMIN} / \mathrm{DF}=1,150$, RMSEA $=0,028$, TLI $=0,971$, CFI $=0,976$, GFI $=0,930$, AGFI $=0,906)$. Statistik dan estimasi kesesuaian disajikan pada Gambar 1. Estimasi pengaruh antar variabel menunjukkan bahwa kualitas pelayanan memiliki pengaruh positip dan signifikan ( $\mathrm{p}$ $<0,05$ ) dominan terhadap kepuasan pelanggan dilanjutkan terhadap niat berkunjung kembali. Sedangkan kualitas produk tidak memiliki hubungan signifikan terhadap kepuasan para wisatawan pantai Long Malang. Hasil ini dan berdasarkan pemeriksaan koefisien jalur, maka Hipotesis 1, dan 3 didukung oleh hasil penelitian, sedangkan Hipotesis 2 tidak didukung. Temuan pada penelitian ini menunjukkan bahwa konsep kualitas pelayanan dan hubungan strukturalnya dengan konstruksi lain yang terkait dengan perilaku konsumen pada wisatawan, cukup dijelaskan dalam model penelitian yang diusulkan. Kualitas pelayanan memiliki efek langsung pada kepuasan, hasil penelitian ini mendukung terhadap temuan penelitian yang dilakukan oleh Wantara (2015), Woodruff (1997) dan Chang dan Wildt (1994), disamping itu variabel kepuasan memiliki efek langsung terhadap niat berkunjung kembali hasil ini mendukung terhadap temuan yang disampaikan oleh Meng \& Han, 2018, Chen \& Tsai, (2007); dan Kim et al. (2015). Dengan hasil ini menunjukkan bahwa kepuasan pelanggan bisa memainkan peran mediasi dalam hubungan antara kualitas pelayanan dan niat berkunjung kembali. Perilaku ketidak puasan atau keluhan bukan menjadi faktor yang signifikan terhadap niat ulang berkunjung wisatawan. Ini mungkin karena konsumen merasa bahwa kondisi pandemi dipahami banyak kendala atau batasan-batasan yang tidak perlu dikeluhkan, apalagi harus melakukan keributan. Temuan ini juga konsisten dengan yang diperoleh dalam studi pelayanan partisipasi wisata sebelumnya, di mana kepuasan pelanggan ditemukan memiliki pengaruh positif yang signifikan terhadap niat ulang berkunjung.

Sementara itu diperoleh temuan bahwa kualitas produk tidak memberi pengaruh signifikan terhadap kepuasan, hal ini menggambarkan bahwa para pengunjung (wisatawan) tidak begitu tertarik terhadap produk yang ditawarkan oleh para penjual atau pengelola destinasi pantai disamping itu para wisatawan datang ke pantai tunjuannya selain untuk menghilangkan kepenatan juga yang paling penting adalah keinginan untuk meningkatkan imun pada kondisi pandemi Covid 19 ini, sebab keyakinan di benak para wisatawan bahwa udara pantai dianggap sangat bagus, jauh dari polusi sehingga dapat meningkatkan daya imun mereka. Sehingga hasil penelitian ini tidak mendukung penelitian yang telah dilakukan oleh Jahanshahi et al. (2011), Amanah (2010).

Selanjutnya dalam penelitian ini, diperoleh temuan bahwa hubungan antara kualitas layanan terhadap kepuasan merupakan hubungan yang dominan dan kuat, 
apabila dibandingkan hubungan antara variabel kepuasan terhadap variabel niat ulang berkunjung maupun hubungan antara kualitas produk terhadap kepuasan. Oleh karena itu, pengelola destinasi wisata pantai harus melakukan apa saja untuk meningkatkan kepuasan konsumen di kalangan pelanggan dalam kondisi New Normal saat ini. Hasil ini juga mendukung gagasan bahwa kualitas layanan destinasi wisata pantai yang ditingkatkan akan dapat meningkatkan keunggulan kompetitif. Hasil studi ini, yang dilakukan pada destinasi wisata pantai Madura, pada dasarnya konsisten dengan hasil yang dilakukan pada negara maupun budaya lain yang berbeda. Sangat penting bagi pengelola destinasi wisata, ketika mengembangkan program, atau kegiatan baru, untuk memahami faktor-faktor yang secara substansial mempengaruhi perilaku konsumsi mereka. Pentingnya mengenali konsumen baru atau konsumen wisata dari luar daerah atau luar negeri yang bersemangat, mandiri, dan layak, telah disorot dalam penelitian ini. Konsumen sangat aktif mengikuti berbagai fasilitas yang disediakan oleh destinasi wisata Long Malang, karena mereka menyadari pentingnya dan manfaat dari hidup sehat dengan mengunjungi destinasi wisata pantai sehinga bisa menjaga dan meningkatkan kesehatan maupun imun mereka.

Temuan kami selanjutnya menunjukkan bahwa pengelola destinasi wisata harus sering memantau kualitas pelayanan dalam rangka mempertahankan pelayanan berkualitas tinggi, mencegah atau meminimalisir kesalahan pelayanan, dan segera menyelesaikan masalah yang tidak terduga. Pengelola harus terus mencari cara inovatif untuk menjangkau pasar konsumen dari luar kota Sampang atau Madura serta memenuhi kebutuhan dan tujuan kesehatannya. Misalnya, pengelola dapat membawa informasi tentang destinasi pantai Long Malang ke sekolah-sekolah dan kelompok komunitas sehingga dapat menyediakan pelayanan yang disesuaikan.

\section{Keterbatasan Penelitian}

Hasil penelitian ini telah memberikan sejumlah temuan, akan tetapi masih ada beberapa hal yang perlu dikaji lebih lanjut. Kondisi ini sangat dipengaruhi oleh beberapa hal yang secara tidak langsung menjadi keterbatasan bagi peneliti, yaitu:

1. Penelitian ini tidak membedakan segmen pelanggan/pengguna jasa, sehingga sulit untuk mengetahui perbedaan pada masing-masing karakteristik pengguna jasa wisatawan.

2. Penelitian ini dilakukan pada objek yang banyak digunakan oleh masyarakat sehingga kualitas layanan sangat diperhatikan.

3. Penelitian ini hanya dilakukan berdasarkan cross-sectional data, sedangkan untuk mengetahui loyalitas sebaiknya dilakukan secara longitudinal sehingga dapat dilakukan pengujian antara niat dan perilaku sebenarnya, hal ini tidak dapat dilakukan mengingat waktu penelitian sangat terbatas.

4. Spesifikasi model yang dikembangkan dalam penelitian ini masih tergolong sederhana dan bersifat umum sehingga belum diperoleh hasil yang benar-benar kompleks.

\section{KESIMPULAN DAN SARAN}

Penilitian dalam kondisi pandemi Covid 19 memiliki banyak keunikan, diantaranya para responden atau masyarakat pengunjung destinasi wisata pantai Long Malang harus tetap menjaga protokol kesehatan, juga adanya jumlah pengunjung yang dibatasi atau tidak seramai sebelum terjadinya pandemi Covid 19. Namun hasil temuan 
penelitian ini diharapkan dapat memberikan gambaran informasi tentang sebuah pelayanan dalam kondisi pandemi.

Hasil penelitian ini dapat disimpulkan bahwa kualitas layanan yang disampaikan oleh pengelola destinasi wisata pantai Long Malang memberikan pengaruh positip dan signifikan terhadap kepuasan para wisatawan, namun kualitas produk yang disampaikan atau dijual oleh pengelola maupun pedagang tidak memberikan pengaruh signifikan terhadap kepuasan para wisatawan. Temuan selanjutnya, bahwa kepuasan para wisatawan memberikan pengaruh signifikan terhadap niat berkunjung kembali para wisatawan ke pantai Long Malang. Niat ulang untuk mengunjungi pantai Long Malang, ini memberikan gambaran bahwa wisatawan lokal Madura, sangat membutuhkan fasilitas pendukung dalam rangka meningkatkan imun kesehatan.

\section{REFERENSI}

Amanah, D. (2010). Pengaruh Harga Dan Kualitas Produk Terhadap Kepuasan Konsumen Pada Majestyk Bakery \& Cake Shop cabang H, M, Yamin Medan. Jurnal Keuangan \& Bisnis. 2 (1), 71-87

Ayuningtiyas, G. A., Nimran, U., \& Hamid, D. (2014). The Influence Word of Mouth (Wom) on Revisit Intention: The Mediating Role of Destination Image (Case Study on Domestic Tourists Visiting Mount Bromo). Profit: Jurnal Administrasi Bisnis Universitas Brawijaya, 8(1). https://doi.org/10.9876/10.9876/ VOL1ISSN1978 -743X

Babbie, E (2004) The Practice of Social Research. Belmont, CA: Thomson/Wadsworth.

Baker, D. and Crompton, J. 2000. Quality, satisfaction and behavioral intentions. Annals of Tourism Research, 27, 785-804.

Bei, L.-T., \& Chiao, Y.-C. (2001). An Integrated Model for The Effect of Perceived Product, Perceived Service Quality, And Perceived Price Fairness on Consumer Satisfaction And Loyalty. Journal of Consumer Satisfaction, Dissatisfaction and Complaining Behavior. 14, 125-140.

Brucks, M., Zeithaml, V. A., \& Naylor, G. (2000). Price and Brand Name as Indicators of Quality Dimensions for Consumer Durables. Journal of the Academy of Marketing Science. 28 (3), 359-374.

Chen, C. F., \& Tsai, D. C. (2007). How destination image and evaluative factors affect behavioral intentions? Tourism management, 28(4), 1115-1122. http://dx.doi.org/10.1016/j.tourman.2006.07.007

Chang, T.-Z., \& Wildt, A. R. (1994). Price, product information, and purchase intention: An empirical study. Journal of the Academy of Marketing Science, 22, 16-27.

Dayour, F., \& Adongo, C. A. (2015). Why They Go There: International Tourists' Motivations and Revisit Intention to Northern Ghana. American Journal of Tourism Management, 4(1), 7-17. https://doi.org/10.5923/j.tourism.20150401.02

Diapinsa Gema Zakaria, (2017), Pengaruh Kualitas Pelayanan, Kualitas Produk Dan Harga Terhadap Kepuasan Pelanggan, Jurnal Ilmu dan Riset Manajemen, Volume 6, Nomor 4. 
Du Plessis, J.L. (2010). Statistical consultation services, Department of Statistics, Potchefstroom, North-West University.

Etemad-Sajadi, R. and Rizzuto, D. (2013), "The antecedents of consumer satisfaction and loyalty in fast food industry: a cross-national comparison between Chinese and Swiss consumers", International Journal of Quality \& Reliability Management, Vol. 30 No. 7, pp. 780-798.

Gaspersz, V. (2002). Pedoman implementasi program six sigma terintegrasi dengan ISO 9001: 2000, MBNQA, dan HACCP. PT. Gramedia Pustaka Utama, Jakarta.

Guntoro, B. and Hui, T.K. 2013.Travel Satisfaction and Revisit Intention of Chinese Visitors: The Case of Singapore. Advances in Hospitality and Leisure, 9, 29-47.

Hassan, M., Hassan, S., Nawaz, M. S., \& Aksel, D. I. (2013). Measuring Customer Satisfaction and Loyalty Through Service Fairness, Service Quality And Price Fairness Percaption: An Empirical Study Of Pakistan Mobile Telekommunication Sector. Science International Journal (Lahore), 25 (4), 971-980.

Hoch, S. J., \& Deighton, J. (1989). Managing what consumers learn from experience. Journal of Marketing, 53, 1-20.

Jahanshahi, A. A., Gashti, M. A., Mirdamadi, S. A., Nawaser, K., \& Khaksar, S. M. (2011). Study the Effects of Customer Service and Product Quality on Customer Satisfaction and Loyalty. International Journal of Humanities and Social Science. 1 (7), 253-260

Kotler, P. and Keller K.L. (2016), Marketing Management. 15thed. Boston: Pearson Prentice Hal

Kotler, Philip and Kevin Lane Keller, 2012. Manajemen Pemasaran di Indonesia: Analisis, Perencanaan, Implementasi dan Pengendalian. Salemba Empat, Jakarta.

Kwon, H. H., Trail, G., \& James, J. (2007). The mediating role of perceived value: Team identification and purchase intention of team-licensed apparel. Journal of Sport Management, 21, 540-554.

Lamb, K., Asturias, L., Roberts, K., \& Brodie, D. (1992). Sports participation - How much does it cost? Leisure Studies, 11, 19-29.

Ngoc, K. M \& Trinh, N. T., (2015). Factors Affecting Tourist' Return Intention towards Vung Tau City, Vietnam-A mediation Analysis of Destintaion Satisfaction. Journal of Advanced Management Science, 3 (4), pp. 292-298.

Macintosh, E., \& Doherty, A. (2007). Reframing the service environment in the fitness industry. Managing Leisure, 12, 273-289.

Meng, B., \& Han, H. (2018). Working-holiday tourism attributes and satisfaction in forming word-of-mouth and revisit intentions: Impact of quantity and quality of intergroup contact. In Journal of Destination Marketing and Management (Vol. 9, pp. 347-357). https://doi.org/10.1016/j.jdmm.2018.03.009

Nunnally, J.C., 1978. "Pshycometric Theory", New York: McGraw-Hill.

Oliver, R.L. (1997), Satisfaction: A Behavioral Perspective on the Consumer, McGraw-Hill, New York, NY. 
Oliver, Richard L. (1999), “Whence Consumer Loyalty?” Journal ofMarketing, 63 (4), 33-44.

Parasuraman, Valarie A. Zeithaml, dan Leonard L. Berry. 1988. SERVQUAL: A Multiple-Item Scale for Measuring Consumer Perceptions of Service Quality. Journal of Retailing, 64 (1), 12-40.

Sambandam, R., \& Lord, K. R. (1995). Switching behavior in automobile markets: A consideration- sets model. Journal of the Academy of Marketing Science, 23, 5765 .

Sciffman, Leon dan Lesslie Lazar Kanuk. 2007. Perilaku Konsumen. Edisi Ketuju. Jakarta: PT. Indeks.

Sharma, P. (2012). Offshore Outsourcing of Customer Services - boon or bane? Journal of Services Marketing. 26 (5), 352-364.

Sugiyono. (2001). Metode Penilaian. Bandung: Alfabeta.

Tjiptono, F., \& Chandra, G. (2011). Service Quality Satisfaction. Yogyakarta: Andy.

Tsuji, Y., Bennett, G., \& Zhang, J. (2007). Consumer satisfaction with an action sports event. Sport Marketing Quarterly, 16, 199-208.

Wahyu Eko Saputro, Sukimin, Nina Indriastuty, (2020), Analisis Daya Tarik Wisata, Persepsi Harga, Dan Kualitas Pelayanan Terhadap Minat Berkunjung Ulang Dengan Kepuasan Konsumen Sebagai Variabel Intervening, (Studi pada Pantai Manggar Segara Sari Balikpapan), Jurnal GeoEkonomi, Volume 11 Nomor 1.

Wantara, P., (2015). The Relationships among Service Quality, tourists Satisfaction, and tourists Loyalty in Library Services. International Journal of Economics and FinancialIssues, Volume 5, pp. 264-269.

Woodruff, R. B. (1997). Customer value: The next source for competitive advantage. Journal of the Academy of Marketing Science, 25, 139-153.

Wu, H. C., Ai, C. H., Yang, L. J., \& Li, T. (2015). A Study of Revisit Intentions, Customer Satisfaction, Corporate Image, Emotions and Service Quality in the Hot Spring Industry. Journal of China Tourism Research, 11(4), 371- 401. https://doi.org/10.1080/19388160.2015.1110545

Yiannakis, A. (1989). Toward an applied sociology of sport: The next generation. Sociology of Sport Journal, 6, 1-16.

Zhafira Raihana, Putu Yudi Setiawan, 2018, Anteseden Kepuasan Pelanggan Dan Dampaknya Pada Niat Pembelian Ulang, E-Jurnal Manajemen Unud, Vol. 7, No. 4, 2018: 1892-1919.

Zeithaml, V. A., Bitner, M. J. \& Gremler, D. (2003). Services marketing: Integrating customer focus across the firm. Boston, MA: McGraw-Hill.

Zhang, J., Lam, E., Cianfrone, B., Zapalac, R., Holland, S., \& Williamson, D. (2011). An importance-performance analysis of media activities associated with WNBA game consumption. Sport Management Review, 14, 64-78. 